\title{
Assessing residency time and habitat use of juvenile smalltooth sawfish using acoustic monitoring in a nursery habitat
}

\author{
Lisa D. Hollensead ${ }^{1,4, *}$, R. Dean Grubbs ${ }^{1}$, John K. Carlson ${ }^{2}$, Dana M. Bethea ${ }^{3}$ \\ ${ }^{1}$ Florida State University Coastal Marine Laboratory, St. Teresa, FL 32358, USA \\ ${ }^{2}$ NOAA NMFS Panama City Laboratory, Panama City, FL 32408, USA \\ ${ }^{3}$ NOAA NMFS Southeast Regional Office, St. Petersburg, FL 33701, USA \\ ${ }^{4}$ Present address: University of North Carolina Wilmington, Wilmington, NC 28403, USA
}

\begin{abstract}
Highly productive, protected habitats have been shown to serve as nurseries for many marine fishes. However, few studies quantitatively measure the biotic characteristics that often drive a habitat's function as a nursery. We used a combination of passive acoustic monitoring and quantification of biotic attributes to assess nursery habitat use of juvenile smalltooth sawfish Pristis pectinata. Acoustic receivers were deployed within Everglades National Park to quantify residency, identify the timing of emigration, and detect migration of juvenile smalltooth sawfish. Benthic grain size and organic content along with mangrove prop root density and limb overhang were quantified throughout the array to test for relationships between habitat attributes and smalltooth sawfish presence. Results indicated that sawfish moved quickly through deep water, narrow creeks, and rivers between shallow tidally influenced bays. A stepwise regression analysis of detections per hour indicated that sawfish had an increased probability of being encountered in areas with high prop root density. Observed residency within the nursery ranged from days to several months with some overwintering, which has never previously been documented in Everglades National Park. Given the large amount of individual variability of movement within the study area, future studies of juvenile smalltooth sawfish habitat in Everglades National Park should strive to investigate the relationships between occurrence and other potential drivers of habitat use such as prey fish assemblage and relative flow at multiple spatiotemporal scales.
\end{abstract}

KEY WORDS: Pristis pectinata $\cdot$ Nursery $\cdot$ Habitat use $\cdot$ Movement $\cdot$ Conservation $\cdot$ Management

\section{INTRODUCTION}

Discrete coastal habitats that are highly productive, such as bays and estuaries, have been shown to serve as nursery areas for many marine fishes (Carlson \& Straty 1981, Meyer et al. 2000, Beck et al. 2001), including elasmobranchs (Castro 1993, Holland et al. 1993, Carlson et al. 2008). Simple abundance of juvenile elasmobranchs within a particular area has been argued as insufficient evidence of essential fish habitat (Musick 1999). Temporal pat-

*Corresponding author: 1dh7520@uncw.edu terns in occurrence, presence of refugia, adequate foraging opportunity, and recruitment contribution to the adult population should also be investigated as part of delineating nursery habitat (Heupel et al. 2007). Investigating and interpreting how areas directly function as nursery habitats is arduous and has led to calls for the refining of key theory concepts in fish (Kraus \& Secor 2005, Dahlgren et al. 2006), including elasmobranchs (Froeschke et al. 2010). In addition, it has been speculated that it may be more appropriate to apply a spatially fluid definition of

() L. D. Hollensead, R. D. Grubbs and, outside the USA, the US Government 2018. Open Access under Creative Commons by Attribution Licence. Use, distribution and reproduction are unrestricted. Authors and original publication must be credited.

Publisher: Inter-Research · www.int-res.com 
nursery habitats, particularly for mobile species where multiple areas may be used within the larger nursery habitat. For mobile species or species that exhibit ontogenetic shifts during the juvenile stage, nursery habitats would function more as a landscape mosaic where movement pathways connect several areas of high occurrence in a spatial network (Nagelkerken et al. 2015). Incorporating all possible nursery habitat theoretical considerations is especially confounded when investigating essential fish habitat of rare or endangered species where fish occurrences may be constrained to potential nursery core areas for only a part of their juvenile phase (Simpfendorfer et al. 2010).

Coastal habitats, including backwater portions of estuaries, within southwest Florida from Charlotte Harbor to Florida Bay function as nursery habitat for the smalltooth sawfish Pristis pectinata, an elasmobranch listed as endangered under the US Endangered Species Act (ESA) in 2003 (Poulakis et al. 2011, Hollensead et al. 2016, NMFS 2003). Subsequently, this region has been designated under the ESA as critical habitat (NMFS 2009, Norton et al. 2012). Sawfish in this region experience high growth rates within the first year of life (Simpfendorfer et al. 2008). Rapid juvenile growth is typical of many batoids (Simpfendorfer et al. 2008, Dale \& Holland 2012), and in sawfish, may facilitate a rapid decrease in predation risk as potential predators such as bull sharks Carcharhinus leucas, lemon sharks Negaprion brevirostris, and American crocodiles Crocodylus acutus co-occur in these inshore areas (Wiley \& Simpfendorfer 2007).

Once a nursery area is identified, few studies quantitatively measure the environmental and physical characteristics of these areas that drive their function as a nursery habitat (but see e.g. Morrissey \& Gruber 1993a,b, Grubbs et al. 2007, Knip et al. 2011). Identifying environmental and physical habitat characteristics that are correlated with species presence can aid conservation biologists when developing management plans for exploited species and recovery plans for rare or endangered species (Simpfendorfer et al. 2010), as well as conserving designated critical habitat. Movement patterns and habitat use studies for smalltooth sawfish using active and passive acoustic telemetry methods that have been previously conducted in Everglades National Park (ENP) (Simpfendorfer et al. 2010) and the Caloosahatchee and Peace rivers (Poulakis et al. 2011, 2013, Huston et al. 2017). These studies indicated that juveniles have small daily activity spaces (Simpfendorfer et al. 2010, Hollensead et al. 2016) and identified areas of persistent occurrence (e.g. nursery hotspots) (Simpfendorfer et al. 2010, Poulakis et al. 2011, Scharer et al. 2017). Additionally, electivity indices using environmental data suggest juvenile affinities for salinities of 18 to 30 , water temperatures $>30^{\circ} \mathrm{C}$, dissolved oxygen levels $>6 \mathrm{mg} \mathrm{l}^{-1}$, water depths $<1 \mathrm{~m}$, and close proximity to red mangrove shorelines (Simpfendorfer 2006, Wiley \& Simpfendorfer 2010, Poulakis et al. 2011). Expanding on this work, directly examining the relationship between juvenile smalltooth sawfish presence with mangrove attributes and quantification of benthic variables can aid in identifying discrete areas for conservation management planning.

We examined juvenile smalltooth sawfish movement within the backwater region of the northernmost portion of ENP. Discrete areas of persistent occurrence of juvenile smalltooth sawfish within this portion of the park are well documented (Seitz \& Poulakis 2002, Poulakis \& Seitz 2004, Wiley \& Simpfendorfer 2010), but the mechanisms driving use of these discrete locations are not fully understood. This study expands on previous studies of habitat use (Simpfendorfer et al. 2010, 2011) by creating variable selection models based on passive acoustic telemetry that predict the most informative physiobiotic habitat parameters as they relate to juvenile smalltooth sawfish presence, and may help illuminate uncertain aspects of the species' juvenile ecology in a relatively pristine environment.

\section{MATERIALS AND METHODS}

\section{Study area}

The study area was located within the northernmost portion of ENP, Florida, from the west side of Chokoloskee Island to the Lopez River (Fig. 1). Chokoloskee Island is opposite the mouth of the Turner River near the southeastern end of Chokoloskee Bay. The east side of Chokoloskee Bay connects to the Turner River in the north and the Lopez River in the south. Within the Turner River and east through Hurdles Creek lies a small mangrove island in Mud Bay that has been identified as a smalltooth sawfish Pristis pectinata area of high occurrence over repeated years (Simpfendorfer et al. 2010). East of Mud Bay through a series of narrow creeks is the 3 bay system called Cross Bays that connects to the Wilderness Waterway to the east and the Lopez River via Crooked Creek to the south. 


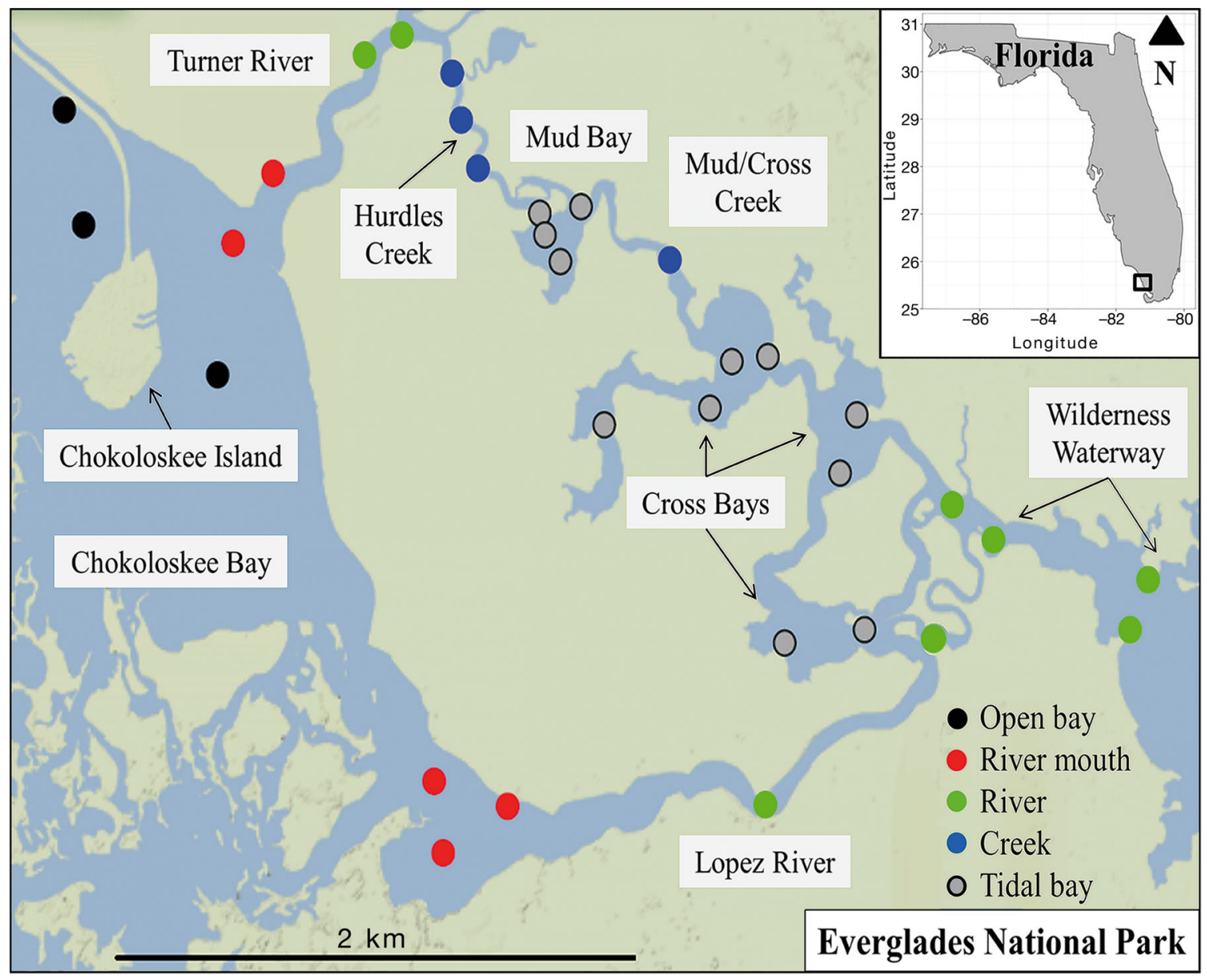

Fig. 1. Study site in southwest Florida within Everglades National Park. The sub-regions Mud Bay, Cross Bays, and the Wilderness Waterway are connected via the Turner River (northern corridor) and the Lopez River (southern corridor). Chokoloskee Island (top left) is surrounded by Chokoloskee Bay and is connected to the mainland by a man-made causeway. Dots indicate the 32-station acoustic monitoring receiver array. Receivers were classified as 5 different habitat types depending on their locations. Receivers were clustered at 3 possible corridors (river mouths and along the Wilderness Waterway) to observe emigration timing from any of the tidal bays

\section{Acoustic array}

An array of 32 VR2W acoustic receivers (VEMCO) was placed within the study area following permit no. EVER-2011-SCI-0010 (Fig. 1). The array was designed to assess backwater residency by smalltooth sawfish, and identify possible corridors for emigration. Receivers were classified into 5 location categories (from backwater to open water): tidal bays, creeks, rivers, river mouths, and open bays.

Each VR2W was attached in the upright position to a $2.5 \mathrm{~cm}$ diameter, $60 \mathrm{~cm}$ long piece of PVC cemented into one side of a concrete masonry block. The open side of the masonry block was attached via stainless steel chain to a $5 \mathrm{~cm}$ diameter PCV pole driven into the substrate. The VR2W, concrete masonry block, and chain constituted one receiver station, and weighed approximately $20 \mathrm{~kg}$ when dry. This anchoring method was designed to keep the VR2W upright and close to the bottom, maximizing the monitoring radius.

Each VR2W was range-tested to evaluate detection distance and to verify that tagged fish could not pass through the array undetected (Fig. 2). A tag was towed behind a kayak through the entire array at the approximate speed of the tidal current. Areas of overlapping VR2W detection coverage were used as acoustic monitoring gates. Gates were located at the mouth of the Turner River, the mouth of the Lopez River, and the entrance to Sunday Bay (not included in Fig. 1) via the Wilderness Waterway to maximize the probability that fish would be detected when entering or leaving the system. Data were downloaded and all VR2Ws were cleared of fouling every month for the duration of the study. 


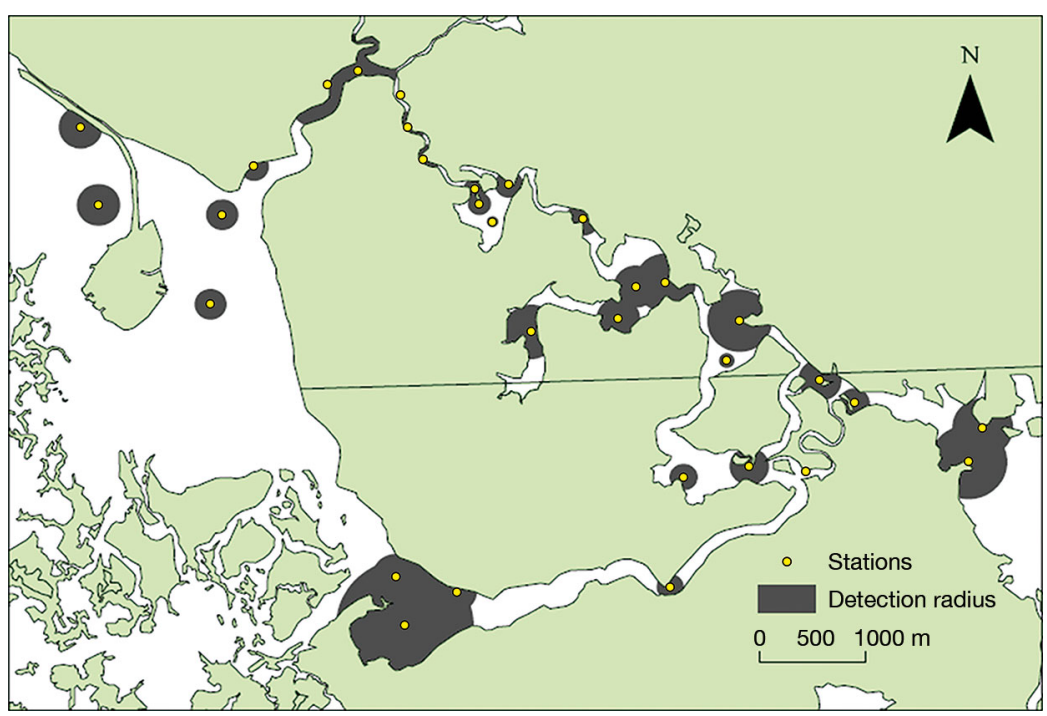

Fig. 2. Everglades National Park study area. Yellow dots: location of VR2W stations; grey areas: detection radius of the receivers as determined by range testing. Horizontal line (mid-figure): Collier county boundary (cm); STL was used in all analyses. All fish were $<150 \mathrm{~cm}$, the approximate size at age-1 (Simpfendorfer et al. 2008, Scharer et al. 2012), and were fitted with either a VEMCO V9 or V13 (depending on fish size) 1-L Global Coding tag (VEMCO) by affixing the tag to a Primer 1 Swivel ${ }^{\mathrm{TM}}$ Ear Tag (Premier1Supplies) using epoxy. The swivel tag was attached through the most anterior portion of the first dorsal fin as close to the body as possible. The thicker connective tissue in this region contains little vascularization or enervation and allowed for better tag retention. Tags emitted an acoustic signal at $69 \mathrm{kHz}$ on a nominal delay of $60 \mathrm{~s}$ and had a battery life of approximately $150 \mathrm{~d}$ for V9 tags and $300 \mathrm{~d}$ for V13 tags. Fish were also tagged with an external dart tag (Floy Tag \& Mfg.) at the base first dorsal fin and an internal passive integrated transponder tag (Biomark) at the base of the second dorsal fin to aid recapture detection.

When a tagged smalltooth sawfish was within detection range of a VR2W, the tag's unique ID, date, and time of day were recorded and archived. If a tagged smalltooth sawfish was detected at least twice on a receiver within one $24 \mathrm{~h}$ period, the individual was recorded as present that day. Single daily detections were omitted to eliminate the possibility of counting a false detection. Residency time was calculated as the sum of days present within any part of the array.

\section{Habitat characterization}

half a daily tidal cycle $(\sim 6 \mathrm{~h})$, and cleared of catch every $0.5 \mathrm{~h}$ or immediately if any fish was observed in the gear. Due to shallow depths at net locations (usually $<0.5 \mathrm{~m}$ ), abiotic factors were measured at the surface; salinity (practical salinity scale), dissolved oxygen $\left(\mathrm{mg} \mathrm{l}^{-1}\right)$, and temperature $\left({ }^{\circ} \mathrm{C}\right)$ were taken at every net location using a YSI-85 environmental meter (YSI).

Captured smalltooth sawfish were carefully removed from the gillnet for processing. Processing took $<10 \mathrm{~min}^{\mathrm{fish}}{ }^{-1}$, during which the fish's mouth and spiracles remained underwater to allow for gill ventilation and stress reduction. Rostral, precaudal, fork, and stretch total lengths (STL) were measured
The physical habitat characteristics considered were sediment composition, mangrove prop root density, and limb overhang. These parameters were selected based on the species' life history and ecology as a demersal batoid, and observational encounters with increased proximity to mangrove shorelines (Simpfendorfer 2006, Simpfendorfer et al. 2010).

Sediment samples were obtained either by hand using a small gardening trowel and a $19 \mathrm{~cm}$ square quadrat to a depth of $10 \mathrm{~cm}$ (i.e. at low tide or in clear water at depths $<1 \mathrm{~m}$ ) or by a $6.8 \mathrm{~kg}$ ponar 'grab' sampler from a boat deck (e.g. in turbid water or at depths $>1 \mathrm{~m})$. Sediment samples used for ana- 
lysis were adjacent to the mid-point of the net. Approximately $0.5 \mathrm{l}$ of sediment was kept from each sample, stored in a Whirl-Pak ${ }^{\mathrm{TM}}$ (NASCO) and frozen until grain size examination. From the 0.51 sample, approximately $30 \mathrm{ml}$ was used for grain size analysis. Upon examination, a P200 sieve was used to distinguish between the sand and silt/clay complex while a P270 sieve separated the silt and clay particles. Samples were analyzed for grain size and percent organic content by a material engineering lab (Terracon Industries) in accordance with American Society for Testing Materials (tests ASTM D2974 and ASTM D422).

Red mangrove Rhizophora mangle morphology was assessed adjacent to each VR2W and within each receiver's detection radius. A $1.5 \mathrm{~m}$ PVC pole with equal lengths $(1.5 \mathrm{~m})$ of rope attached to each end was placed perpendicular to the shoreline at the first grounded prop root encountered, and the ropes were thrown into the mangroves, creating an openended quadrat. This method was developed due to the typically high mangrove prop root density along undisturbed, mature red mangrove shorelines within ENP. A prop root was counted only if it made complete contact with the ground; close clumps $(<10 \mathrm{~cm})$ of 2 or more prop roots were counted as 1 . In cases where prop roots were too dense to count individually, estimates were taken by multiplying the number of structures along 2 sides of the quadrat. The length of limb overhang was measured (in $\mathrm{m}$ ) perpendicular from the PVC pole of the open-ended quadrat out to the tip of the farthest overhanging limb using a measuring tape. These measurements were repeated 2 more times by moving $6 \mathrm{~m}$ to either side of the first measurement area along the shoreline to calculate an average for the sampled area. By moving $6 \mathrm{~m}$, we ensured that we were $>3$ times the maximum limb overhang, and avoided any potential pseudoreplication by taking multiple measurements of the same mangrove tree. Repeating the measurements at this distance gave a holistic representation of the shoreline. The 3 values were averaged for each receiver station and used as the mangrove variables in the habitat model.

\section{Habitat models}

Habitat models were constructed using VR2W records for each station as a dependent variable. Three different dependent variables were calculated and tested. The first calculation was used to test for possible variable selection over a longer temporal scale (fish $\mathrm{wk}^{-1}$ ), the second calculation was used to determine the probability of detecting a specific sawfish within an area (detections fish ${ }^{-1}$ $\mathrm{h}^{-1}$ ), and the third was used to determine the probability of detecting any sawfish within an area (detections $\mathrm{h}^{-1}$ ). Binary responses were recorded as 0 for any receiver that did not record a fish or detection during the examination time period and 1 for any fish or detection recorded at a particular receiver. The dependent variables were tested as functions of percent sediment organic matter, percent sediment silt, prop root density (per $2.25 \mathrm{~m}^{2}$ ), and limb overhang. Spearman's rank correlation tests were used to assess correlations between variables before they were processed in the model, where a value $>0.5$ indicated a strong correlation (i.e. collinearity).

The habitat model was constructed using a stepwise logistic regression as a means of variable selection. All possible combinations of variables were tested, starting with a null model with no variables to a full model using all variables for each dependent variable. Models were run using generalized linear model (GLM) framework. Variables were retained in the models if statistically significant $(p<0.05)$. All analyses were performed using $\mathrm{R}$ statistical software ( $\mathrm{R}$ Development Core Team 2011).

\section{RESULTS}

\section{Acoustic monitoring}

A total of 21 juvenile smalltooth sawfish Pristis pectinata were tagged within the study site: 5 in Mud Bay, 12 on the west side of Chokoloskee Island along the causeway, and 4 on the east side of Chokoloskee Island along the causeway (Table 1). All tagged fish except one (Sawfish 3305) were recorded by at least 1 receiver in the array and all but 2 receivers (CC2 and WW3) detected tagged smalltooth sawfish. Presence in the array was variable and ranged from 1 to $197 \mathrm{~d}$ with a total monitoring period of $334 \mathrm{~d}$ (Fig. 3).

Of the 5 fish tagged in Mud Bay, 3 exited through the Lopez River mouth between mid-May and midJune. Sawfish 346 and 341 exited Mud Bay in early June and early July respectively. Both emigrated from tidal bay habitats into the Wilderness Waterway area, turned, and moved out of the system via the Lopez River (Fig. 4A). Once in the Lopez River mouth, the 2 paths diverged. Sawfish 346 was last detected in the Lopez River mouth in mid-June and 
Table 1. Juvenile smalltooth sawfish Pristis pectinata $(\mathrm{n}=21)$ tagged with either a V9 or V13 acoustic tag within the study site by location tagged, ID, and capture date during 2011. Chok: Chokoloskee; STL: stretch total length; days detected: number of days a particular sawfish was detected $(>1$ recording) on any receiver anywhere within the study area

\begin{tabular}{|c|c|c|c|c|c|}
\hline Sub-region & ID & $\begin{array}{c}\text { Capture date } \\
\mathrm{mo} / \mathrm{d}\end{array}$ & $\begin{array}{l}\text { STL } \\
(\mathrm{cm})\end{array}$ & Sex & $\begin{array}{c}\text { Days } \\
\text { detected }\end{array}$ \\
\hline \multirow[t]{5}{*}{ Mud Bay } & 338 & $4 / 25$ & 85.0 & $\mathrm{~F}$ & 100 \\
\hline & 339 & $4 / 25$ & 87.0 & $\mathrm{~F}$ & 91 \\
\hline & 340 & $4 / 25$ & 86.5 & F & 30 \\
\hline & 341 & $4 / 27$ & 89.0 & M & 102 \\
\hline & 346 & $5 / 26$ & 93.0 & $\mathrm{~F}$ & 2 \\
\hline \multirow{12}{*}{$\begin{array}{l}\text { Chok. Island } \\
\text { (West) }\end{array}$} & 344 & $6 / 18$ & 88.0 & $\mathrm{~F}$ & 11 \\
\hline & 345 & $6 / 18$ & 95.5 & M & 14 \\
\hline & 347 & $7 / 26$ & 98.5 & $\mathrm{~F}$ & 23 \\
\hline & 1748 & $8 / 25$ & 120.0 & M & 20 \\
\hline & 1749 & $8 / 25$ & 120.0 & $\mathrm{~F}$ & 44 \\
\hline & 1750 & $8 / 25$ & 127.0 & F & 17 \\
\hline & 1751 & $8 / 25$ & 113.0 & F & 26 \\
\hline & 1752 & $8 / 25$ & 107.0 & M & 18 \\
\hline & 3305 & $9 / 21$ & 131.0 & $\mathrm{~F}$ & 0 \\
\hline & 3307 & $10 / 22$ & 83.0 & M & 11 \\
\hline & 3309 & $10 / 22$ & 85.0 & $\mathrm{~F}$ & 29 \\
\hline & 3310 & $10 / 22$ & 85.0 & M & 56 \\
\hline \multirow{4}{*}{$\begin{array}{l}\text { Chok. Island } \\
\text { (East) }\end{array}$} & 342 & $5 / 23$ & 95.0 & $\mathrm{~F}$ & 14 \\
\hline & 343 & $5 / 23$ & 90.0 & $\mathrm{~F}$ & 1 \\
\hline & 1753 & $8 / 25$ & 118.0 & F & 28 \\
\hline & 3308 & $9 / 21$ & 128.0 & F & 1 \\
\hline
\end{tabular}

was not detected again during the study period (Fig. 4A, question mark). Sawfish 341 left the Lopez River in mid-July and was detected on a Chokolos-

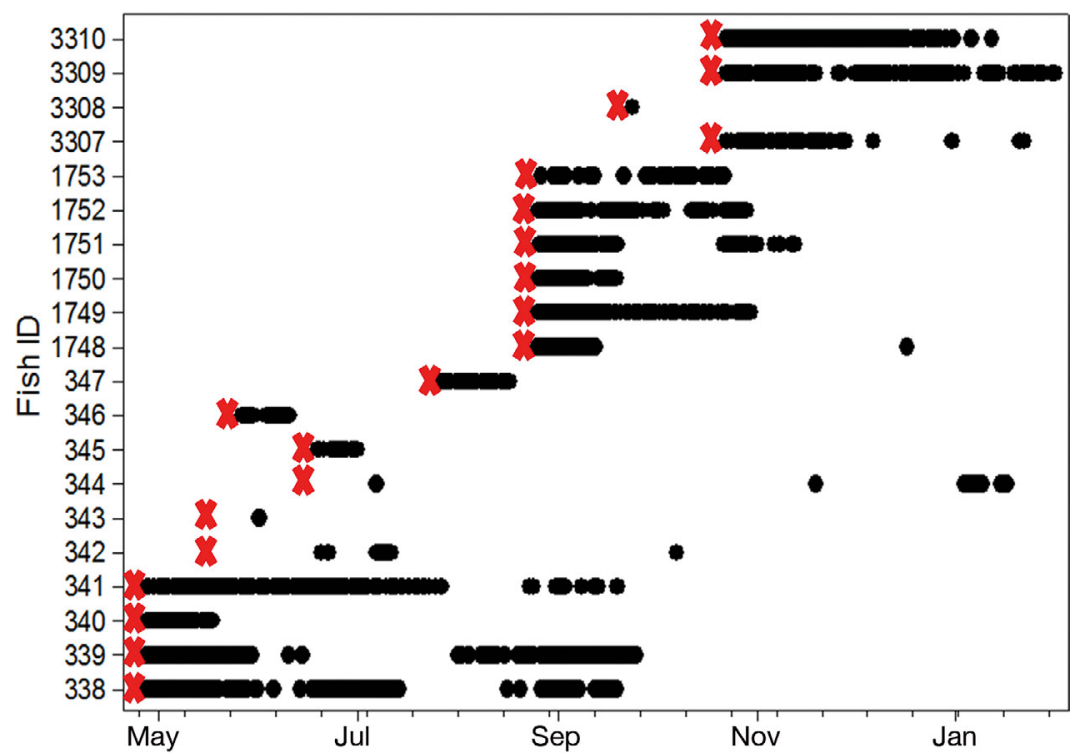

Fig. 3. Residency times for all smalltooth sawfish Pristis pectinata tagged in 2011 in the Everglades National Park study area. Crosses: date the fish was acoustically tagged. Black dots: date a sawfish was deteced on VR2W station and considered present within the study area. See Table 1 for catch details kee Bay receiver a few days later. Sawfish 341 remained in Chokoloskee Bay until late September when the acoustic tag battery presumably expired (Fig. 4A, hexagon). Two other fish tagged in Mud Bay (Sawfish 338 and 339) moved into adjacent Cross Bays and remained there until the tags presumably expired (on approximately 3 October 2011).

Sawfish 340 exhibited behavior that differed from other study fish (Fig. 4B). Initially, movement from Mud Bay to the neighboring Cross Bays was observed in late May. However, this individual quickly returned to Mud Bay after entering the adjacent Cross Bay, and made a rapid movement through Mud Bay into the mouth of the Turner River before turning again back towards Mud Bay again. After passing through Mud Bay, Sawfish 340 was then observed to move through all 3 Cross Bays before being last detected mid-Lopez River. Given the rapid and indiscriminate movement of this individual from other sawfish observations, it is difficult to determine whether this behavior was indicative of high individual variability or a result of predation (e.g. by a bull shark Carcharhinus leucas).

As opposed to the directed movement exhibited by sawfish tagged in Mud Bay, the 16 juveniles tagged in Chokoloskee Bay generally remained within the bay over the winter and into the following spring; 15 of these fish never moved between rivers or other smaller tidal bay areas (Fig. 5). The exception, Sawfish 342, alternated from the east side of Chokoloskee Island along the causeway into Turner River for a period of $4 \mathrm{~d}$ before finally settling in Chokoloskee Bay, where it remained until the tag presumably expired. Most fish tagged on the west side of Chokoloskee Island remained there for the summer and fall (July through October) and $\geq 3$ fish (Sawfish 3307, 3309, and 3310) overwintered there (November through February).

The above findings are in contrast to fish tagged in Mud Bay, that were not observed to overwinter in Mud Bay and showed directed movement through the study site during the summer (June through July), allowing for further examination of habitat selection. Since juveniles tagged in Chokoloskee Bay tended to reside within the habitat in which they were tagged and never displayed movement between the adjoining rivers, there was not enough spatial 

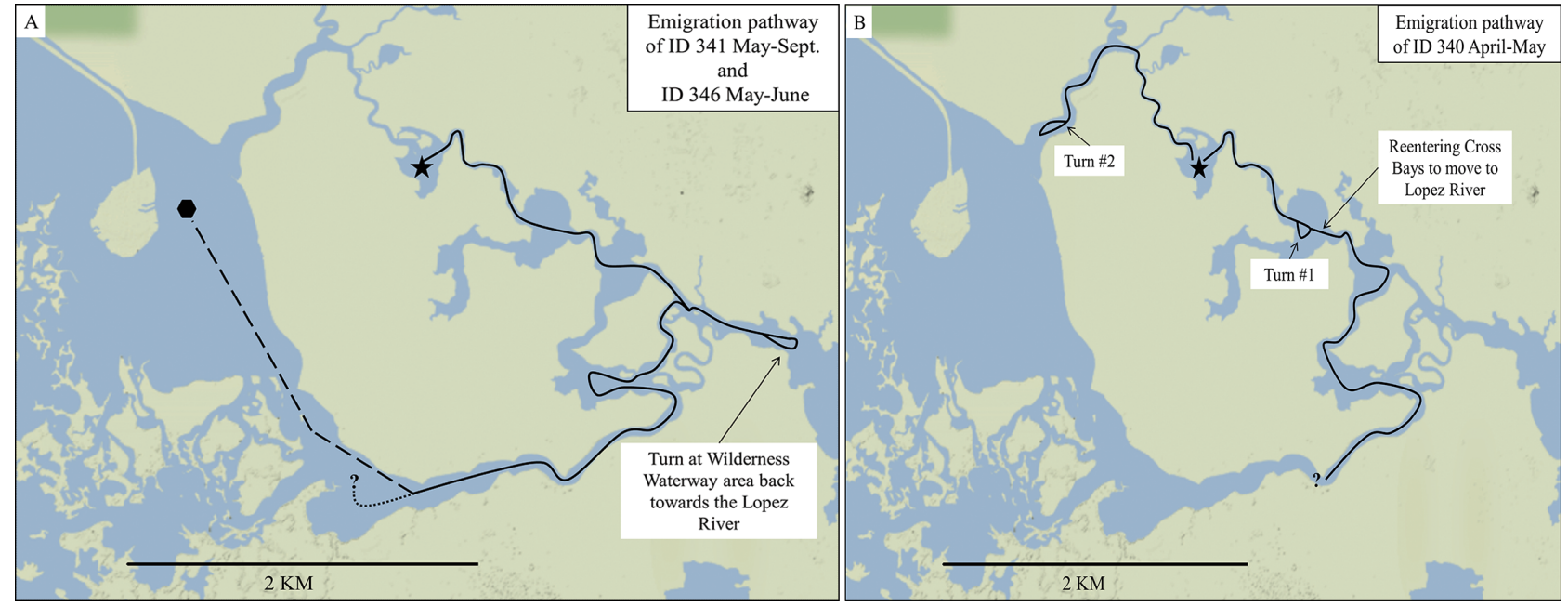

Fig. 4. (A) Initial observed movement from Mud Bay (star) by 2 juvenile smalltooth sawfish Pristis pectinata (Sawfish 341 and 346). After emigrating via the Lopez River, Sawfish 346 was last detected within the river mouth (question mark) and Sawfish 341 was detected within Chokoloskee Bay until probable tag expiration (hexagon). (B) Initial observed migration from Mud Bay (star) by Sawfish 340. This individual was last detected within the Lopez River (question mark). Given the rapid and indiscriminate movement of this individual compared to other sawfish observations, it is difficult to determine whether this behavior is indicative of high individual variability or a result of a possible predation event (e.g. by a bull shark Carcharhinus leucas)

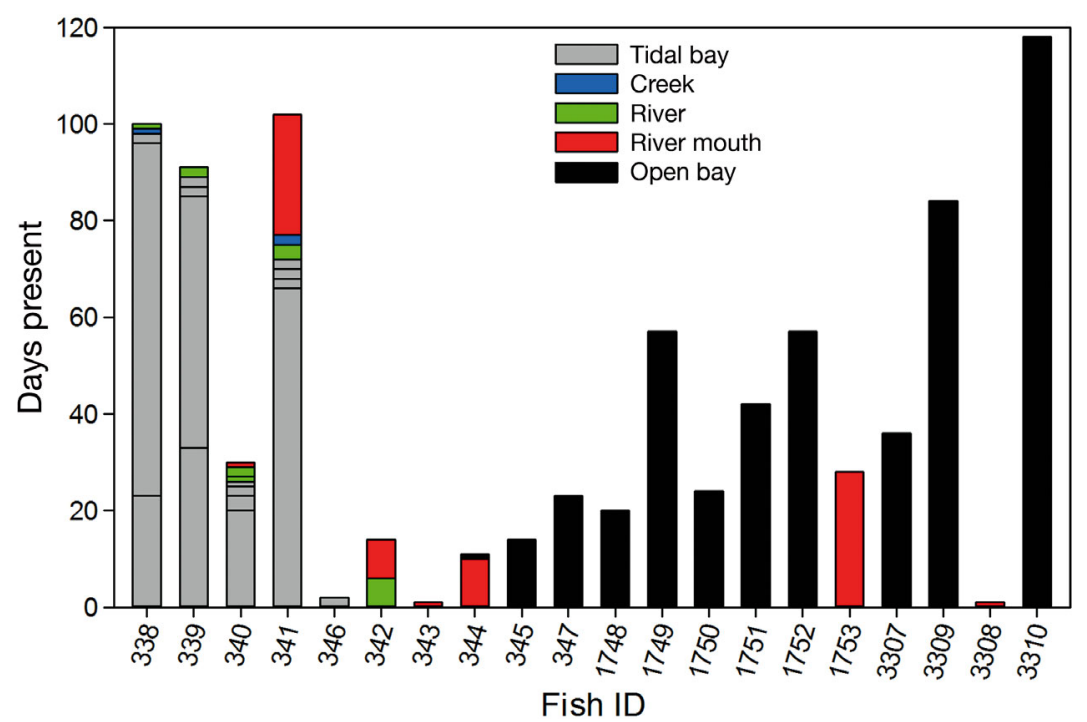

Fig. 5. Days present within a location category (from backwater to open water): tidal bays, creeks, rivers, river mouths, and open bays. Fish ID: individual juvenile smalltooth sawfish Pristis pectinata. The first 5 columns are the fish tagged in Mud Bay, the middle 12 fish were tagged on the west side of Chokoloskee Island, and 4 fish were tagged on the east side of Chokoloskee Island; however, Sawfish 3305 was never detected on a study receiver and is not included in the figure. See Table 1 for catch details

resolution to quantify potential drivers for habitat selection. However, since observed migration events were monitored for Mud Bay emigrants through the study area, those observations were used to construct the 3 logistic models to assess habitat use based on measured habitat attributes (Fig. 6).

\section{Habitat models}

There was low to moderate correlation between predictor variables (Table 2). The strongest correlations were between mangrove prop root and limb overhang (rho $=0.54)$ and sediment silt and organic composition (rho = $0.57)$. We expected significant correlations (i.e. collinearity) in these cases but retained all variables for model construction, since the objective was to compare the effects of habitat use and accumulation of habitat features (e.g. size of mangroves) in relation to habitat selection by smalltooth sawfish.

Logistic regressions were run for each of the 3 dependent variables. For the models testing dependent variables fish $\mathrm{wk}^{-1}$ and detections fish ${ }^{-1} \mathrm{~h}^{-1}$, no predictor variables were significant, though detections of monitored fish were somewhat greater in areas with high prop root density when testing detections $\mathrm{h}^{-1}$ (GLM: standard estimate $=$ 0.61 , error $=0.32, t=1.97, \mathrm{p}=0.06$ ) (Table 3). A subsequent stepwise regression analysis of detections $\mathrm{h}^{-1} \mathrm{in}$ corporating all habitat variables indicated that smalltooth sawfish had an increased probability of being encountered in areas with high prop root density (stepwise GLM: partial $\mathrm{r}^{2}=0.22, \mathrm{C}(\mathrm{p})=6.02, \mathrm{p}=0.023$ ). 


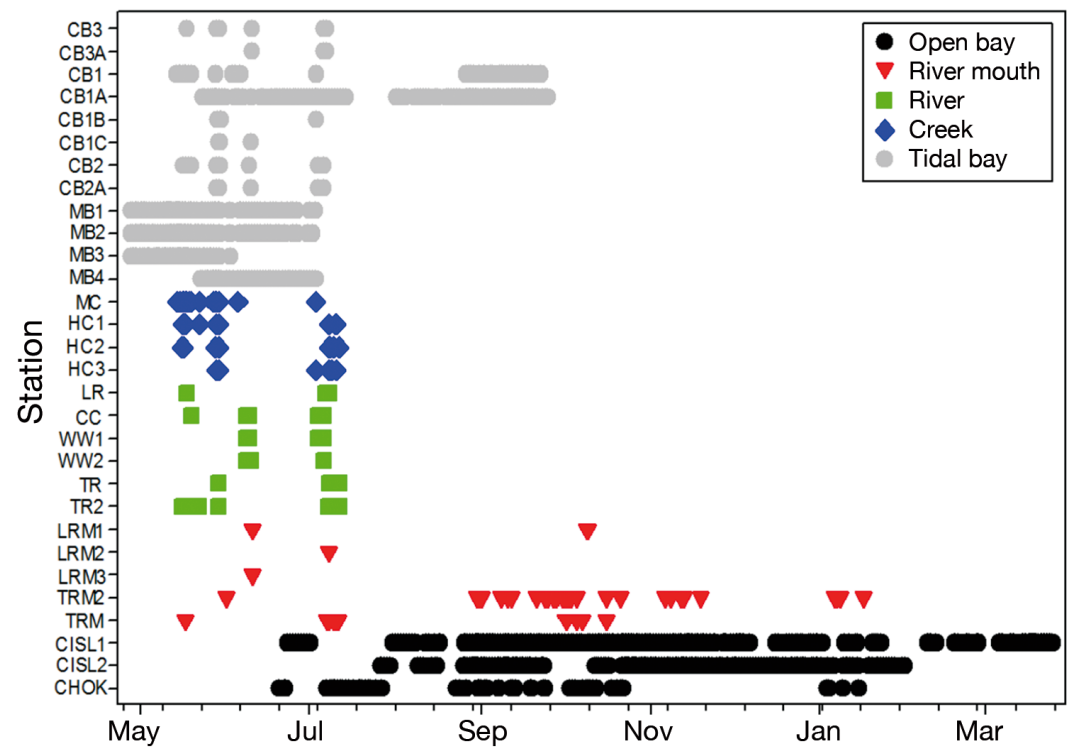

Fig. 6. Habitat use of tagged juvenile smalltooth sawfish Pristis pectinata. Each color corresponds to the broad habitat delineation outlined in Fig. 1. Station labels on the $y$-axis indicate receivers in specific areas: $\mathrm{CB}=$ Cross Bays; $\mathrm{MB}=$ Mud Bay; $\mathrm{MC}=$ Mud/Cross Creek $; \mathrm{HC}=$ Hurdles Creek; LR = Lopez River; $\mathrm{CC}=$ Cross Creek; WW $=$ Wilderness Waterway; $\mathrm{TR}=$ Turner River $;$ LRM $=$ Lopez River Mouth; TRM = Turner River Mouth; CISL $=$ Chokoloskee Island ( 2 receivers on west side of island), and CHOK $=$ Chokoloskee Bay (single receiver on the east side of Chokoloskee Island). Two VR2W receivers (CC2 = Crooked Creek 2 and WW3 = Wilderness Waterway 3) never detected a tagged fish and are not included in the figure

Table 2. Rho values resulting from the Spearman's rank correlation test between all variables. Asterisks: significantly correlated values (>0.30). Prop root density and limb overhang were correlated $(\mathrm{rho}=0.54)$ as well as percent organic sediment and percent silt sediment (rho $=0.57)$; these collinear variables were retained for model construction since the objective was to compare the effects of habitat use and accumulation of habitat features (e.g. size of mangroves) in relation to habitat selection by smalltooth sawfish

\begin{tabular}{|lcccc|}
\hline Habitat variable & Organic & Silt & Overhang & Prop root \\
\hline Organic & - & & & \\
Silt & $0.57^{*}$ & - & & \\
Limb overhang & -0.02 & 0.24 & - & \\
Prop root & 0.07 & 0.23 & $0.54^{*}$ & - \\
\hline
\end{tabular}

\section{DISCUSSION}

This study is the first to document overwintering of juvenile smalltooth sawfish Pristis pectinata within nursery habitats in northern ENP, and increased the previously reported residency time within the nursery (Simpfendorfer et al. 2010). Previous acoustic monitoring studies of Mud Bay had reported similar findings to this study, indicating that juveniles left the bay during the summer months (average time present was $16.8 \mathrm{~d}_{\text {; Simpfen- }}$ dorfer et al. 2010). However, the previous study examined residency just within Mud Bay using only 3 acoustic receivers. In the current study, the monitoring array was more extensive spatially, which allowed us to document greater residency times within the broader nursery habitat and investigate potential migration corridors from Mud Bay. While the underlying drivers influencing departure from Mud Bay remain unclear, similar behavior was observed between individuals tagged in the bay. Emigration occurred during the summer months (June through July) and was always directed towards the neighboring tidal bays to the southeast (Cross Bays). All observed movement from the tidal bays (i.e. Mud Bay and Cross Bays) used the Lopez River as the emigration corridor. Given the similar size, temperature, and salinity of the Turner and Lopez rivers, it is unclear why juveniles exited Mud Bay via the Lopez River and not the Turner River. Data recorded by US Geological Survey (USGS) tidal stations indicated nearly identical maximum daily observations for temperature and salinity during the study period (Fig. 7A). While no discharge flow rate data were available for the Turner River for comparison, data recorded from the Lopez River station indicated generally low flows that were predominately directed towards the backwater study areas (negative values) with a transition to higher magnitude flows downriver during the fall period (Fig. 7B). Additionally, model investigations using the Linked Overland/ Aquifer Density Dependent System (FTLOADDS) indicated that flows in the Turner River may be relatively higher than the Lopez River (Wang et al. 2007).

Juveniles exhibited rapid movement through creeks and rivers but longer residency in tidal bays. Juvenile smalltooth sawfish have been shown to demonstrate strong affinity for shallow near-shore habitat associated with mangroves within ENP (Hollensead et al. 2016). This species is dorsal-ventrally flattened, and it is hypothesized that it may be most successful in avoiding predation by selecting very shallow near-shore habitats that are not as easily accessible to larger, deeper-bodied predators. Deeper channels such as those in creeks and rivers within 
Table 3. Results of 3 sets of logistic regressions (GLM). Dependent variables (fish $\mathrm{wk}^{-1}$, detections fish ${ }^{-1} \mathrm{~h}^{-1}$, and detections $\mathrm{h}^{-1}$ ) were all tested as a function of 4 habitat variables (density of mangrove prop roots, mangrove limb overhang, percent silt sediment, and percent organic sediment). No variables were significant for any of the dependent variables. The model testing the dependent variable detections $\mathrm{h}^{-1}$ resulted in a $\mathrm{p}$-value for mangrove prop root density that was closest to being significant

\begin{tabular}{|c|c|c|c|c|}
\hline Dependent/Habitat variable & Standard estimate & Error & $t$ & $\mathrm{p}$ \\
\hline \multicolumn{5}{|l|}{ Fish $w^{-1}$} \\
\hline Intercept & 3.09 & 1.1 & 0.35 & 0.73 \\
\hline Prop root density & 0.02 & 0.03 & 0.76 & 0.46 \\
\hline Limb overhang & 0.06 & 0.32 & 0.19 & 0.85 \\
\hline Percent silt & -0.02 & 0.07 & -0.34 & 0.74 \\
\hline Percent organic & 0.06 & 0.05 & 1.19 & 0.25 \\
\hline \multicolumn{5}{|l|}{ Detections fish ${ }^{-1} h^{-1}$} \\
\hline Intercept & 7.58 & 4.7 & 1.61 & 0.12 \\
\hline Prop root density & 0.01 & 0.14 & 0.09 & 0.93 \\
\hline Limb overhang & 1.78 & 1.38 & 1.29 & 0.21 \\
\hline Percent silt & -0.11 & 0.3 & -0.36 & 0.72 \\
\hline Percent organic & $3.00 \times 10^{-3}$ & 0.21 & 0.02 & 0.99 \\
\hline \multicolumn{5}{|l|}{ Detections $\mathbf{h}^{-1}$} \\
\hline Intercept & -0.36 & 10.55 & -0.03 & 0.97 \\
\hline Prop root density & 0.61 & 0.32 & 1.97 & 0.06 \\
\hline Limb overhang & 1.78 & 3.1 & 0.02 & 0.98 \\
\hline Percent silt & $-2.40 \times 10^{-5}$ & 0.67 & 0 & 1 \\
\hline Percent organic & -0.12 & 0.48 & -0.25 & 0.81 \\
\hline
\end{tabular}

of the gillnet gear that was fishing deeper (i.e. farther away from the shoreline) than the portion of the gear located directly at the shoreline (D. Bethea unpubl. data). Therefore, it would be advantageous for any habitat expansion from Mud Bay to include adjacent tidal bays. In this case, the neighboring larger Cross Bays may serve as a habitat that could support a rapidly growing juvenile while still providing refuge from predators. Cross Bays may act as a staging area prior to initiation of movement to Chokoloskee Bay through the Lopez River, whereas habitat expansion directly into the Turner River, with no neighboring shallow tidal bay potentially acting as refugia, would expose smaller migrating juveniles to potentially increased predation risks, which may require a more saltatory movement and may be more energetically taxing. Even expansions into nearby tidal bays pose risks of predation. A potential the study area (D. Bethea pers. obs.) would be more accessible to large predators and be higher-risk habitats for juvenile sawfish (Wang et al. 2007). Over the course of the study, it was common to catch juvenile bull sharks Carcharhinus leucas or lemon sharks Negaprion brevirostris in the portion predation event of Sawfish 340 at $\sim 01: 00 \mathrm{~h}$, while the tagged individual was attempting to traverse a creek connecting Mud Bay to Cross Bays, was observed in the telemetry results; Sawfish 340 was recorded by the receivers as making rapid, erratic movements that differed from all other study fish.

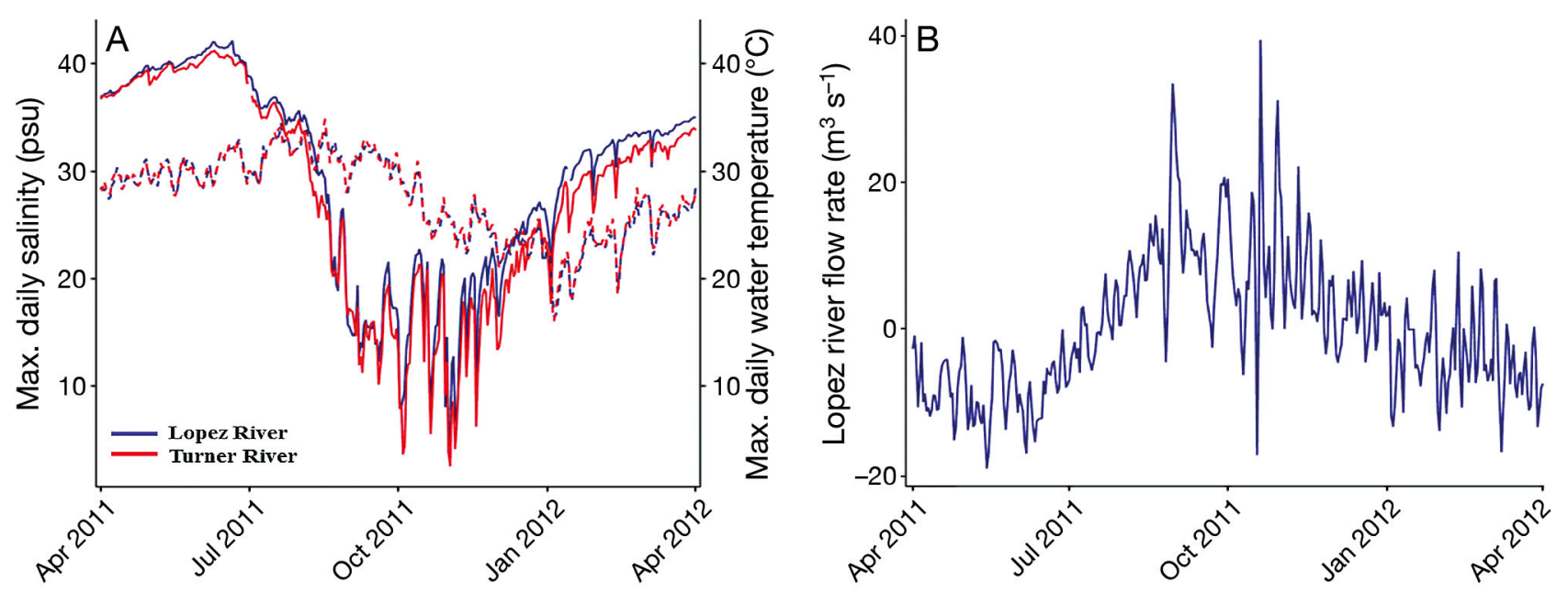

Date

Fig. 7. (A) Maximum daily salinity (solid lines) and temperature (dashed lines) for the Lopez (blue) and Turner (red) rivers during the study period. (B) Flow rate values for the Lopez River (no tidal flow data were available for the Turner River) during the study period. Negative values indicate reverse flow towards the backwater region of the study area and positive values indicate tidal flows moving downriver towards the river mouth 
Potential shifts in the occurrence of forage fish within the study area may also influence the seasonal patterns of movement of smalltooth sawfish. Youngof-the-year and larger juvenile smalltooth sawfish are piscivorous (Poulakis et al. 2017), and seasonal spatial shifts in prey fish abundance could serve as a driver for this observed movement. Following migrating prey fish may also explain why the Lopez River served as an emigration corridor rather than the Turner River. Future studies examining habitat attributes as explanatory variables for habitat selection involving smalltooth sawfish should also incorporate surveys of the seasonal abundance and species richness of prey fish communities to better understand these relationships. However, this remains speculative. Another possible explanation for smalltooth sawfish movement may be physiological, whereby it may be advantageous to seek optimal water temperatures for metabolic processes.

The numerically and spatially larger acoustic array implemented in this study also allowed for monitoring of Chokoloskee Island, a previously unmonitored area. Chokoloskee Island is a small island community $\left(0.6 \mathrm{~km}^{2}, 359\right.$ people) in southeast Collier County, FL, connected to Everglades City via a man-made causeway built in 1955, and is the only anthropogenically altered area in the study system. Both sides of the causeway are now red mangrove-lined, and the west side of the causeway is an area of high juvenile sawfish occurrence (e.g. a nursery hotspot) (D. Bethea unpubl. data). In this area, there is evidence based on our telemetry observations of year-round habitat use when water temperatures remain habitable (23 to $28^{\circ} \mathrm{C}$ ); individuals tagged there remained for much of the monitoring period, and exhibited little to no movement into the surrounding tidal bay areas like Mud Bay.

Similar to Chokoloskee Island, other anthropogenically influenced areas in southwest Florida are juvenile smalltooth sawfish areas of high occurrence (nursery hotspots). The Caloosahatchee River, a more anthropogenically affected area than Chokoloskee Island, is also within designated critical habitat for juvenile smalltooth sawfish (NMFS 2009). The designation of juvenile critical habitat was implemented based on persistent documentation of young-of-the-year and juvenile smalltooth sawfish in the Caloosahatchee River across many years (Seitz \& Poulakis 2002, Poulakis et al. 2011, 2013, Norton et al. 2012). Movement within the Caloosahatchee River is sometimes limited, with tagged individuals exhibiting high residency to their tagging locations (Poulakis et al. 2016). While some diel movements have been observed (Poulakis et al. 2016), larger directed movements throughout the river were often associated with freshwater flow changes (Poulakis et al. 2013) and storm events (Poulakis et al. 2016) as water flow in the Caloosahatchee River is managed by the South Florida Water Management District. Genetic evaluation of juveniles in the Caloosahatchee River revealed that young-of-the-year captured together were from different mothers, indicating that adult females may give birth in specific areas (Poulakis et al. 2016).

Juvenile smalltooth sawfish may be using Chokoloskee Island similarly to sites along the Caloosahatchee River. Areas around the island were observed to have longer residency times than Mud Bay, but the reasoning remains unclear. Mud Bay is relatively close to Chokoloskee Island $(\sim 3.2 \mathrm{~km})$ and would theoretically be subjected to similar salinities and water temperatures. It may be possible that Chokoloskee Island is more accessible to females giving birth and, since movement is limited for juveniles at this size (Hollensead et al. 2016, Poulakis et al. 2016), residency in this area may be higher. Smalltooth sawfish in ENP are subject to a more natural freshwater flow regime compared to those in the Caloosahatchee River; they are never prompted to move long distances due to rapid abiotic changes in the environment necessitated by water management issues. However, it is unclear if the natural seasonality of flow regimes, or larger storm systems such as hurricanes, would affect this residency pattern in our study site.

Greater residency within shallow tidal areas rather than creeks may also be explained by flow regimes. Narrow creeks in particular are subject to relatively higher flow during ebb and flood tides than more open bays and river mouths. These currents may influence swim speeds of juvenile smalltooth sawfish, and act as a physical driver for more rapid movement through narrow creeks. We never observed fish tagged in Chokoloskee Bay entering the river or creek systems of the backwater region. Perhaps juveniles are not yet physically developed enough to counter strong head currents, or lack the experience to use an advantageous denatant current if they have never been exposed to fast-moving flows. It is unclear whether increased flow rate, changes in salinity, or a combination of these factors can explain this behavior or how juveniles in ENP may respond to such environmental changes. Regardless of the underlying behaviors, our study indicates that narrow, deep, high-energy areas were not habitat types used by small juveniles. 
No sediment variables were shown to predict smalltooth sawfish presence. Much of the benthic material was homogenous throughout the study area with fine-silt particles dominating the system; perhaps the lack of contrast in grain size and organic content was not sufficient to demonstrate any relationship. It is also possible that it is not the benthic composition but some other attribute we failed to measure such as the benthic grade (e.g. slope). Regardless, it is likely that the loss or redistribution of suitable benthic habitat due to anthropogenic influences such as sea level rise could influence the habitats ultimately selected. Future studies should seek to further refine the benthic attributes of areas of high juvenile abundance (nursery hotspots) as well as compare the benthic attributes described in this study to those of other known areas of high use like the Caloosahatchee River.

Previous studies of smalltooth sawfish presence have reported a correlation between habitat use and proximity to mangroves (Simpfendorfer 2006, Hollensead et al. 2016), and our study supports this. Smalltooth sawfish were more likely (albeit not significantly) to be detected in areas with high prop root densities (number of prop roots per $2.5 \mathrm{~m}^{2}$ ), suggesting areas with high mangrove prop root density (i.e. mature red mangrove forest) may be particularly important to conserve for potential juvenile habitat as increased structure has been documented to aid in both foraging and predator avoidance (Laegdsgaard \& Johnson 2001).

Despite the spatial expansion of the acoustic array from previous juvenile sawfish studies (Simpfendorfer et al. 2010), many questions remain concerning the function of ENP has a nursery environment. Our model did not include several seasonal water quality measurements (e.g. water temperature, salinity, or dissolved oxygen). Future studies using acoustic detections to model habitat use should deploy environmental data recorders at receiver locations. Seasonal variation in water quality (specifically salinity) and flow does affect the behavior of smalltooth sawfish in the Caloosahatchee River, where individuals have been observed making movements downriver in response to freshwater releases from the Franklin Lock and Dam (Poulakis et al. 2013). However, whether seasonal environmental variation directly influences smalltooth sawfish movement due to physiological constraints, drives the movement of their fish prey, or some combination of both factors remains unknown. The results of a direct investigation of these drivers would improve our understanding of how ENP functions as a nursery habitat.
Confounding interpretation further is the individual variability of movement observed in this study. In Mud Bay, the directed movement during the summer months indicated that smalltooth sawfish nursery habitat in ENP may be more reflective of the landscape mosaic hypothesis (Nagelkerken et. al. 2015). Yet, these individuals were never detected on the west side of Chokoloskee Island, indicating potential limited activity between 2 neighboring areas of documented high use (nursery hotspots). Still, several other individuals exhibited constrained seasonal movements and remained adjacent to Chokoloskee Island during the winter months (November through February). This variability makes empirical testing of habitat nursery theory difficult. Future smalltooth sawfish nursery habitat use studies in ENP should expand the spatial scale of the study, as the small area of our study and low sample size may have not been sufficient to capture any evidence of a habitat mosaic.

\section{CONCLUSIONS}

Spatial considerations for conservation planning require rigorous empirical investigation to identify and understand the underlying functions of essential fish habitats, particularly for endangered species. Within their nursery habitats in ENP, juvenile smalltooth sawfish select low-flow, shallow tidal bays, and river mouths in close proximity to mature red mangrove shorelines. These habitats likely provide higher prey abundance and offer greater protection from predators, and as such, should be conserved. Juvenile smalltooth sawfish in ENP are born in the early spring, shift habitats during the summer, and overwinter within nursery areas, which makes them residents in this area for at least their first year of life. This variability in habitat use may make any spatial or temporal considerations to management planning more complicated; however, it also offers managers insight into the relationship between the environment and smalltooth sawfish early life history. In the future, nursery habitat use studies for smalltooth sawfish should strive to incorporate multi-spatial and temporal examination, and continue to investigate the relationships between habitat selection and habitat attributes such as seasonal shifts in prey fish abundance and flow regime. We know there are similarities in habitat use among smalltooth sawfish nurseries that have been examined to date, and it will be important to document links between these nurseries and adult habitats. 
Acknowledgements. Smalltooth sawfish were collected under guidelines approved by Protected Species Permit \# SEFSC-NMFS-13330. Permission to conduct research in Everglades National Park was approved by permit \# EVER2011-SCI-0010. We thank P. J. Walker, The Wilderness Committee, and Tom Iandimarino, the ENP Gulf Coast District Ranger. This project was funded by a contract through the Florida Fish and Wildlife Conservation Commission (FWC) as part of a National Oceanic Atmospheric Administration's (NOAA) National Marine Fisheries Service (NMFS) Section 6 Protected Species Cooperative Conservation Grant (NA10NMF4720032). We acknowledge Shelley Norton at the NOAA Southeast Regional Office for helping facilitate source funding. We thank Emily DuVal, Don Levitan, Jannie Wulff, and 2 anonymous reviewers for their input on earlier drafts of the manuscript. This project would have been impossible without the following people who contributed long, hot, and mostly unpaid hours in the field: Lisa Ailloud, Jeremy Bender, Josh Boston, Amanda CanningSmith, Chris Custer, Andrew Foley, Ashley Pacicco, Christine Singer, Kelcee Smith, Mollie Taylor, Emily Tewes, and Tonya Wiley-Lescher. This work was presented as part of the symposium 'Biology and Ecology of Sawfishes' at the 2016 annual meeting of the American Elasmobranch Society, which was supported by funding from the Save Our Seas Foundation, Disney Conservation Fund, and the American Elasmobranch Society.

\section{LITERATURE CITED}

Beck MW, Heck KL Jr, Able KW, Childers DL and others (2001) The identification, conservation, and management of estuarine and marine nurseries for fish and invertebrates: a better understanding of the habitats that serve as nurseries for marine species and the factors that create site-specific variability in nursery quality will improve conservation and management of these areas. Bioscience 51:633-641

Carlson HR, Straty RR (1981) Habitat and nursery grounds of Pacific rockfish, Sebastes spp., in rocky coastal areas of southeastern Alaska. Mar Fish Rev 43:13-19

Carlson JK, Heupel MR, Bethea DM, Hollensead LD (2008) Coastal habitat use and residency of juvenile Atlantic sharpnose sharks (Rhizoprionodon terraenovae). Estuar Coast 31:931-940

* Castro JI (1993) The shark nursery of Bulls Bay, South Carolina, with a review of the shark nurseries of the southeastern coast of the United States. Environ Biol Fishes 38: $37-48$

Dahlgren CP, Kellison GT, Adams AJ, Gillanders BM and others (2006) Marine nurseries and effective juvenile habitats: concepts and applications. Mar Ecol Prog Ser 312:291-295

Dale JJ, Holland KN (2012) Age, growth and maturity of the brown stingray (Dasyatis lata) around Oahu, Hawai'i. Mar Freshw Res 63:475-484

Froeschke JT, Stunz GW, Sterba-Boatwright B, Wildhaber ML (2010) An empirical test of the 'shark nursery area concept' in Texas bays using a long-term fisheriesindependent data set. Aquat Biol 11:65-76

Grubbs RD, Musick JA, Conrath CL, Romine JG (2007) Long-term movements, migration, and temporal delineation of a summer nursery for juvenile sandbar sharks in the Chesapeake Bay region. In: McCandless CT, Pratt
HL Jr, Kohler NE (eds) Shark nursery grounds of the Gulf of Mexico and east coast waters of the United States. American Fisheries Society Symposium No. 50, Betheseda, MD, p 87-107

Heupel MR, Carlson JK, Simpfendorfer CA (2007) Shark nursery areas: concepts, definition, characterization and assumptions. Mar Ecol Prog Ser 337:287-297

*Holland KN, Wetherbee BM, Peterson JD, Lowe CG (1993) Movements and distribution of hammerhead shark pups on their natal grounds. Copeia 1993:495-502

Hollensead LD, Grubbs RD, Carlson JK, Bethea DM (2016) Analysis of fine-scale daily movement patterns of juvenile Pristis pectinata within a nursery habitat. Aquat Conserv 26:492-505

*Huston CA, Stevens PW, Blaxton RM, Tolley SG, Scharer RM, Tornwall BM, Poulakis GR (2017) Diel movements of juvenile smalltooth sawfish: implications for defining the size of a nursery hotspot. Endang Species Res 34: 311-322

Knip DM, Heupel MR, Simpfendorfer CA, Tobin AJ, Moloney J (2011) Ontogenetic shifts in movement and habitat use of juvenile pigeye sharks Carcharhinus amboinensis in a tropical nearshore region. Mar Ecol Prog Ser 425:233-246

Kraus RT, Secor DH (2005) Application of the nursery-role hypothesis to an estuarine fish. Mar Ecol Prog Ser 291: 301-305

KLaegdsgaard P, Johnson C (2001) Why do juvenile fish utilise mangrove habitats? J Exp Mar Biol Ecol 257: 229-253

* Meyer CG, Holland KN, Wetherbee BM, Lowe CG (2000) Movement patterns, habitat utilization, home range size and site fidelity of whitesaddle goatfish, Parupeneus porphyreus, in a marine reserve. Environ Biol Fishes 59: 235-242

* Morrissey JF, Gruber SH (1993a) Home range of juvenile lemon sharks, Negaprion brevirostris. Copeia 425-434

*Morrissey JF, Gruber SH (1993b) Habitat selection by juvenile lemon sharks, Negaprion brevirostris. Environ Biol Fishes 38:311-319

Musick JA (1999) Introduction to part 2: essential fish habitat identification. In: Benaka LR (ed) Fish habitat: essential fish habitat and rehabilitation. Symposium 22, Proc Sea Grant Symp 'Fish habitat: essential fish habitat and rehabilitation', August 26-27, 1998, Hartford, CT. American Fisheries Society, Bethesda, MD, p 41

Nagelkerken I, Sheaves M, Baker R, Connolly RM (2015) The seascape nursery: a novel spatial approach to identify and manage nurseries for coastal marine fauna. Fish Fish 16:362-371

NMFS (National Marine Fisheries Service) (2003) Endangered and threatened species; final endangered status for a distinct population segment of smalltooth sawfish (Pristis pectinata) in the United States. Fed Regist 68: $15674-15680$

NMFS (2009) Endangered and threatened species; critical habitat for the endangered distinct population segment of smalltooth sawfish. Fed Regist 74:45353-45378

* Norton SL, Wiley TR, Carlson JK, Frick AL, Poulakis GR, Simpfendorfer CA (2012) Designating critical habitat for juvenile endangered smalltooth sawfish in the United States. Mar Coast Fish 4:473-480

Poulakis GR, Seitz JC (2004) Recent occurrence of the smalltooth sawfish, Pristis pectinata (Elasmobranchiomorphi: Pristidae), in Florida Bay and the Florida Keys, with com- 
ments on sawfish ecology. Fla Sci 67:27-35

Poulakis GR, Stevens PW, Timmers AA, Wiley TR, Simpfendorfer CA (2011) Abiotic affinities and spatiotemporal distribution of the endangered smalltooth sawfish, Pristis pectinata, in a south-western Florida nursery. Mar Freshw Res 62:1165-1177

* Poulakis GR, Stevens PW, Timmers AA, Stafford CJ, Simpfendorfer CA (2013) Movements of juvenile endangered smalltooth sawfish, Pristis pectinata, in an estuarine river system: use of non-main-stem river habitats and lagged responses to freshwater inflow-related changes. Environ Biol Fishes 96:763-778

Poulakis GR, Stevens PW, Timmers AA, Stafford CJ, Feldheim KA, Heupel MR, Curtis C (2016) Long-term site fidelity of endangered smalltooth sawfish (Pristis pectinata) from different mothers. Fish Bull 114:461-475

* Poulakis GR, Urakawa H, Stevens PW, DeAngelo JA and others (2017) Sympatric elasmobranchs and fecal samples provide insight into the trophic ecology of the smalltooth sawfish. Endang Species Res 32:491-506

R Development Core Team (2011) R: a language and environment for statistical computing. R Foundation for Statistical Computing, Vienna

Scharer RM, Patterson WF III, Carlson JK, Poulakis GR (2012) Age and growth of endangered smalltooth sawfish (Pristis pectinata) verified with LA-ICP-MS analysis of vertebrae. PLOS ONE 7:e47850

Scharer RM, Stevens PW, Shea CP, Poulakis GR (2017) All nurseries are not created equal: large-scale habitat use patterns in two smalltooth sawfish nurseries. Endang Species Res 34:473-492

Seitz JC, Poulakis GR (2002) Recent occurrence of sawfishes

Editorial responsibility: Gregg Poulakis (Guest Editor), Port Charlotte, Florida, USA
(Elasmobranchiomorphi: Pristidae) along the southwest coast of Florida (USA). Fla Sci 65:256-266

Simpfendorfer CA (2006) Movement and habitat use of smalltooth sawfish. Mote Marine Laboratory Technical Report No. 1070. Mote Marine Laboratory, Sarasota, FL

Simpfendorfer CA, Poulakis GR, O'Donnell PM, Wiley TR (2008) Growth rates of juvenile smalltooth sawfish Pristis pectinata Latham in the western Atlantic. J Fish Biol 72: 711-723

Simpfendorfer CA, Wiley TR, Yeiser BG (2010) Improving conservation planning for an endangered sawfish using data from acoustic telemetry. Biol Conserv 143: 1460-1469

* Simpfendorfer CA, Yeiser BG, Wiley TR, Poulakis GR, Stevens PW, Heupel MR (2011) Environmental influences on the spatial ecology of juvenile smalltooth sawfish (Pristis pectinata): results from acoustic monitoring. PLOS ONE 6:e16918

Wang JD, Swain ED, Wolfert MA, Langevin CD, James DE, Telis PA (2007) Application of FTLOADDS to simulate flow, salinity, and surface-water stage in the southern Everglades, Florida. US Geological Survey Scientific Investigations Report 2007-5010

Wiley TR, Simpfendorfer CA (2007) The ecology of elasmobranchs occurring in the Everglades National Park, Florida: implications for conservation and management. Bull Mar Sci 80:171-189

Wiley TR, Simpfendorfer CA (2010) Using public encounter data to direct recovery efforts for the endangered smalltooth sawfish Pristis pectinata. Endang Species Res 12: 179-191

Submitted: April 21, 2018; Accepted: August 2, 2018 Proofs received from author(s): September 20, 2018 